\title{
MEASURING TANGIBILITY AND ASSURANCE AS DETERMINANTS OF SERVICE QUALITY FOR PUBLIC HEALTH CARE IN SOUTH- AFRICA
}

\author{
J de Jager \& T du Plooy, Department of Marketing, Tshwane University of Technology, Pretoria.
}

\begin{abstract}
Purpose: The purpose of this research is to measure service quality offered to patients treated in a governmentcontrolled hospital in South Africa.

Design/Methodology/Approach: A service satisfaction survey was conducted amongst patients treated at a provincial hospital in Gauteng. The attitudes of the patients were tested regarding pre-identified service quality aspects related to health care. Tangibility and assurance categories are analysed for the purposes of this paper. A total of 583 in- and out-patients were selected at random and were personally interviewed. A five point Likert type scale was used to measure their expectations and perceived performance.
\end{abstract}

Findings: These indicated patient dissatisfaction with both service quality dimensions measured, although significant differences exist between in- and out-patients. Personal safety and cleanliness of facilities were regarded as the most important variables in the assurance and tangibility dimensions. The level of satisfaction was the highest for clear information signage and communication at an understandable level in the tangibility-and assurance categories, respectively.

Implications: This paper presents a comprehensive framework for prioritising important issues by provincial hospital management policy makers to satisfy patients' expectations and, because they have more authority over expenditure, the findings are important in the interest of supplying acceptable health care.

Originality/Value: This study challenges existing work on health care services. Its significance lies in investigating the diversified health care needs and wants of various cultural groups in South Africa, because it focuses on service quality as experienced by in- and out-patients. It offers a new framework from an original South African perspective, focusing on differences and similarities between in- and outpatients of a Gauteng public hospital.

Key words and phrases: Service quality, health care, provincial hospitals.

\section{INTRODUCTION}

Various authors recognise the strategic importance of service quality in health care in both the private and the public health care organisations (Ramani, 2004:208; Manaf, 2005:205 and Mostafa, 2005:517). Quality should not only be assessed from the provider's point of view, but also from the customer's point of view, while acknowledging the complexity, heterogeneity and ambiguity of health care services. Although it is debatable on exactly how to increase the efficiency and effectiveness of the health care industry, an increasing number of health care organisations are implementing the principles of quality management to improve and maintain the quality of care, while at the same time controlling costs (Eiriz \& Figueiredo, 2005:405).

Even though the strategic importance of quality in the context of health care is widely accepted, significant differences exist between the various health care providers. A recent study in Egypt found, that the level of satisfaction of private hospital patients is higher than those of public hospital patients (Mostafa, 2005:526). The findings of a study by Jabnoun and Chaker (2003:296) in the United Arab Emirates (UAE) indicate the opposite. Public hospital in-patients are overall more satisfied than private hospital in-patients, even more so with regard to reliability and tangible related issues. Explanations for these unexpected results include the proportionally large government investment in health care and the high incidence of patients being subsidised for medical treatment outside the UAE.

It is crucial to understand patients' perceptions and expectations of the quality of care, because the perceived quality of health care services often influences the consumption behaviour and patterns of health services (Baltussen, Haddad \& Sauerborn, 2002:42). Determining the factors associated with 
patient's satisfaction is an important topic for the health care provider in order to understand what is valued by patients, how the quality of care is perceived by the patients and to know where, when and how service changes and improvements could be made.

This article reviews the relevant literature on service quality with the focus on health care, followed by a discussion of the research methodology applied to determine the service quality delivered in a government-controlled hospital in South Africa. The main results of this study are summarised and relevant management implications highlighted.

\section{LITERATURE REVIEW}

The next section presents an overview from an international perspective and background information on the South African health care environment. Thereafter the construct of quality as conceptualised in the service literature and the measurement thereof are presented. Tangibles and assurance are the two dimensions of service quality that are analysed for the purposes of this paper and relevant international and local health care literature is discussed accordingly.

\section{Health Care Management - A Global Overview}

Literature from several countries suggests that health care provision in developing countries across the world faces similar challenges in terms of cost to quality ratios which has an impact on the perceived quality of services rendered to patients as part of those states' general health care service provision (Ramani, 2004:208 and Mostafa, 2005:516)

Patients' expectations and priorities with regards to health care vary among countries and are highly related to cultural background and the local health care system (Salomon, Gasquet, Mounir \& Ravaud, 1999:509). Due to the various challenges faced by governmental hospitals in India, such as: the increase in patient load, while hospital infrastructure remains the same; enormous financial constraints; poor utilisation of resources; and unsatisfactory administrative support from authorities, performance assessment of government hospitals has become vital in order to offer efficient and effective healthcare services (Ramani, 2004:208). Escalating costs in public health care expenditure has also been experienced by the Malaysian government Manaf (2005:2006) and, in Egyptian hospitals, modern technology has been rendered ineffective due to insufficient training (Mostafa, 2005:516). Eiriz and Figueiredo (2005:405) point out that, although health care organisations in Portugal are becoming more marketing-oriented, it is critical for health care providers to maintain high service quality and continuously assess patients' expectations and experiences.

South Africa, as a developing country with a non-homogenous population consisting of several cultural groups, has faced very particular transformation challenges characterised by rapid changes to achieve the goal of providing equitable access to health services to the majority of the population since the end of apartheid in 1994. Despite South Africa's attempt to transform health care, the public health care system is still under-resourced and over-used. Aids and other poverty-related diseases, such as tuberculosis and cholera, are placing a tremendous strain on the country's health care system. Public health has been characterised by a strong public sector component, which consumes around $11 \%$ of the total government's budget (www.southafrica.info). Provincial health departments and local authorities constitute $80 \%$ of the public health sector and this includes hospitals, primary health care, laboratories, and ambulance services (Whittaker, Green-Thomson, McCusker \& Nyembezi, 2000:250). The shortage of staff, basic equipment and medication, basic fundamentals (water, telephone access and reliable electricity) and long patient waiting times are often reported as obstacles in providing quality health care in South Africa (Mahomed \& Bachmann, 1998:123). Mitchell (2000:12) points out that managed care organisations need to prove to their clients that cost containment does not necessarily imply that the quality of services rendered is being compromised.

Ovretveit (2004:370) advocates the improvement of health care quality in the developing countries for the following reasons: increasing patient dissatisfaction with higher costs (mainly private hospitals); low quality in public health care services; raising service quality in order to possibly increase income of health workers; the necessity to increase the efficiency and effectiveness of health care management; and adhering to basic humanitarian principles. It is thus evident, that acceptable health care service delivery directly influences patients' satisfaction levels and is discussed next. 


\section{Service Quality in Health Care}

The state is the primary provider of health services in developing countries and it stands to reason that the patient of a government-controlled hospital is the primary client. Consequently, the evaluation of those services provided by state hospitals, and recommendations made in terms thereof, would enable the managers and policy makers of those institutions to adequately provide the services in terms of their customers' expectations, bearing in mind the difficult balance between cost and quality in health care provision in developing countries.

Grönroos (1990:82) is of the opinion that service quality is the result of what consumers receive and how they perceive it. According to Berry and Parasuraman (1991:81), this implies that clients assess service quality by comparing what they want or expect to their perception of what they actually receive. Several theories on how service expectations are formed can be found in the literature. Oliver (1980:462) describes expectations as consumers' beliefs or predictions of what will happen as the result of a service transaction, while Cadotte, Woodruff and Jenkins (1987:307) consider it to be standards that consumers believe a product should offer. Parasuraman, Zeithaml and Berry $(1985: 42)$ describe expectations as the wants of consumers, that is, what they feel a service provider should offer and perceptions refer to the consumers' evaluation of the service provider. Expectations are influenced by individual consumer characteristics (Oliver, 1980:464), accepted marketing practices, advertising, word of mouth, and past service experiences (O'Connor, Trinh \& Shewchuk, 2000:8). Although the debate on how expectations are formed continues, it can be concluded that they serve as means to evaluate service quality.

Grönroos (1990:97), furthermore, expands on service quality by distinguishing between functional and technical quality. Technical quality in health care is the accuracy of diagnosis and procedures and functional quality refers to the manner of delivery of health care. Sohail (2003:198) is of the opinion that service quality is primarily shaped by functional quality, because patients often find it difficult to assess the technical quality.

Other studies on customer satisfaction in health care emphasise the importance of convenience, access, waiting times, choice, quality of information, range of services, nature of the patient's medical problems, patients' demographic background, a comfortable environment, and a courteous and caring medical staff (Brown \& Swartz, 1989:94; Singh, 1990:12; Sage, 1991:28 and Bansal, 2004:183). Health service quality should, consequently, be regarded as multi-dimensional.

One the one hand, several studies in the services sector have looked at the relationship between service quality and customer satisfaction (Parasuraman, Zeithaml \& Berry, 1994; Cronin \& Taylor, 1992 and Johnson, 1995). Parasuraman, Zeithaml and Berry, (1988:16) are of the opinion that perceived service quality is the overall evaluation of a service over a period of time, while satisfaction is a transaction-specific evaluation, and conclude that perceived service quality is the result of incidents of satisfaction over time. Agreement can be found in the literature that satisfaction refers to the outcome of individual service transactions and the overall service transactions, whereas service quality has a broader meaning and refers to the overall impression of the acceptability of the organisation and its services (Johnson, 1995:56). Zineldin (2006:61) remarks that service quality and the closely related customer satisfaction constructs are of vital concern for health care organisations. The responsiveness towards patients and the continuous improvement of healthcare services and doctor-patients relationships, shape patients satisfaction.

On the other hand, research comparing health care providers on various issues relating to service quality include: the comparison of satisfaction levels with medical care and services between patients and observers of hospital services (families and friends) (Butler, Oswald \& Turner, 1996); the difference in quality of the service provided by public and private hospitals in Egypt (Mostafa, 2005:524) and the United Arab Emirates (Jabnoun \& Chaker, 2003:291); as well as the comparison of health care service quality in different countries: the USA and UK (Kilbourne, Duffy, Duffy \& Giarchi, 2004:526).

\section{Measuring Service Quality}

There exists significant differences between government and private health care providers across the globe (Jabnoun \& Chaker, 2003:293), even more so especially when taking the developmental status 
of countries into consideration. The level of aspiration in terms of service delivery, especially, becomes more problematic and political. It is therefore important to consider a wide spectrum of literature, while at the same time remaining focused on the core issues of measuring service quality in health care and achieving this through a universally accepted and standardised measuring instrument of service quality.

Services have several unique qualities relative to physical goods: they are more intangible, heterogeneous, and consumption and production occurs simultaneously (Grönroos 1990:88 and Parasuraman et al., 1985:42). Consequently, the measurement of service quality, including health care service quality, has to be based on perceived quality rather than objective quality. Service quality is a concept that has aroused considerable interest and debate in the research literature, because of the difficulties in both defining it and measuring it with no overall consensus emerging on either (Parasuraman et al., 1985:43). The most popular model of service quality is SERVQUAL, a set of 22 structured and paired questions designed to assess customers' expectations of service provision and the customers' perceptions of what was actually delivered. This instrument is structured in five dimensions, namely:

- $\quad$ Tangibles: physical facilities, equipment, and appearance of personnel;

- $\quad$ Reliability: ability to perform the promised service dependably and accurately;

- $\quad$ Responsiveness: willingness to help customers and provide prompt service;

- Assurance: knowledge and courtesy of employees and their ability to inspire trust and confidence; and

- $\quad$ Empathy: caring, individualised attention provided to customers (Parasuraman et al., 1988:3543).

This study does not include a detailed discussion of the scale reliability and validity of SERVQUAL for the sake of brevity, but readers can refer to Parasuraman et al. $(1985,1988,1994)$. Although SERVQUAL has been criticised for its conceptualisation, generalisability and dimensionality (Babakus \& Boller, 1992; Cronin \& Taylor, 1992; Lam \& Woo, 1997 and Buttle, 1996), it is widely used by academics and practitioners to measure service quality (Wong, 2002; Youssef, Nel \& Bovaird, 1996:22; Sewel, 1997 and Jabnoun \& Chaker, 2003). Numerous studies on service quality in the health care industry utilised and adopted the SERVQUAL instrument with diverse findings on the dimensions identified (Butler, Oswald \& Turner, 1996:14 and Sohail, 2003:201), as well as the relative importance of the dimensions of service quality (Wong, 2002:210; Youssef, Nel \& Bovaird, 1996:18; Sewel, 1997:22 and Jabnoun \& Chaker, 2003:295).

The assurance perceived by customers is an important dimension of service quality in any industry (Zeithaml et al., 1990:120) but even more so in the health care industry where customers associate quality with perceptions of human factors (Butler, Oswald, Turner, 1996:9). Assurance is especially critical where trust and confidence in the service provider are crucial (Branssington \& Pettit, 2000:950) and this clearly is also applicable to the health care sector (Van Der Schee, Groenewegen, \& Friele, 2006:350). Assurance and the assessment thereof should clearly be an integral part of health care delivery strategy (Ovretveit, 2004:370).

Although tangibility as a service quality dimension is rather simple to manage because people are not really involved, the possible financial constraints in the public health care sector in South Africa should be taken into consideration when it is assessed. In various service quality studies, tangibility has been found to be rather unimportant (Zeithaml et al., 1990:29). However, Boshoff and Gray (2004:33) remark that this is not the case in the hospital environment. This article focuses on assurance and tangibly in public health care in the South-African context. Therefore, an overview of relevant literature on Tangibility and Assurance is presented hereafter, with specific reference to health care.

\section{Tangibility}

Several studies assessing service quality provided in private and public health care included the influence of tangibles and assurance (Sohail, 2003:202; Youssef, Nel \& Bovaird, 1996:15-28; Vandamme \& Leunis, 1993:30-49 and Boshoff \& Gray, 2004:32). It has been argued that the single most important difference between services and products is the characteristic of intangibility and this 
has a significant influence on the marketing management of services (Parasuraman et al., 1985:42 and Grönroos, 1990:96). This often makes it difficult for customers to understand service quality and, as a result, more difficult for businesses to understand how consumers perceive and evaluate a service. Intangibility implies that a consumer's perception of quality is often based on physical evidence and price rather than the core service. Physical evidence refers to the environment in which the service is delivered and where the firm and the customer interact and also any tangible commodities that facilitate performance or communication of the service (Zeithaml \& Bitner, 1996:111). This demonstrates that the physical evidence of a health care service production process can influence the service experience. Parasuraman et al. (1988:37) describe tangibility in SERVQUAL as the "solid" dimension used to assess service quality, while Santos (2002:294) refers to tangibles as the tangible elements of a service and includes aspects such as the appearance of physical facilities, tools and equipment, personnel, and communication material.

Vandamme and Leunis (1993:44) measured service quality in a public hospital in Belgium and found that the most important dimensions explaining overall service quality included tangibility and assurance. Boshoff and Gray (2004:33) investigated the relationship between service quality, customer satisfaction and loyalty (as measured by purchasing intentions) among patients in the private health care industry in South Africa. The study revealed that the service quality dimensions of nursing staff empathy, assurance and tangibles, impact positively on patients' loyalty. Satisfaction with the cleanliness of the hospital and the ward, neatness of the buildings, décor in the wards and appearance of the nursing staff will impact on loyalty. In this study, the importance of the cleanliness of the hospital was confirmed.

Further establishing the significance of tangibility in the perception of service quality in health care, Sohail (2003:202) assesses the quality of services provided by private hospitals in Malaysia and the study revealed that patients' expectations with regard to modern equipment, the visual appearance of facilities, and professional appearance were relatively low but their perceived performance were higher for all of these variables. In this current study, the overall expectations with regards to all items in the tangibly dimension were relatively high with the highest expectations for cleanliness of facilities and the general condition of equipment. It can be expected that the expectations and perceptions will differ between private and public hospitals.

\section{Assurance}

The assurance dimension in SERVQUAL refers to the knowledge and courtesy of employees and their ability to inspire trust and confidence (Parasuraman et al., 1988:40) The inseparability of production and consumption and the co-production of services (Grönroos, 1990:101) implies that the people providing the service play a significant role and therefore the perceptions of the assurance dimension will influence the overall perceived service quality. Health care is a high involvement service and all contact between health practitioners and patients is important and complex (Bansal, 2004:186). This interpersonal aspect of health care is also noted by several other authors (Orava \& Tuominen, 2002:680). The assurance perceived by patients can enhance this interpersonal relationship with health practitioners.

A very recent study in Mauritius explores the benefits that customers expect to receive from private general practitioners. The SERVQUAL dimensions were compared to the items generated in this study. Two additional critical dimensions were suggested, namely professionalism and core medical items, and a few items were added to the original SERVQUAL dimensions. The assurance dimension comprises of the following items: a courteous and friendly physician; courteous and friendly support staff; confidentiality of patient information; the ability of the GP to inspire trust and confidence in a patient; the ability of support staff to inspire trust and confidence in a patient; the thoroughness of explanation of medical condition and treatment; the physicians making patients feel safe and relaxed in their transactions; and the honesty of the physician (Ramsaran-Fowdar, 2005:437). These items were discussed with the management of the hospital in this study and adapted to be more applicable for a public hospital.

The findings on the assurance service quality dimension in terms of importance and perceived performance varies from study to study. Private patients from hospitals in Malaysia had generally low expectations for the assurance dimensions, especially the item of "ability to deal with problems". Their perceptions scores for the performance exceeded their expectations for all of the items (Sohail, 
2003:202). In the current study, it was found that, of the five dimensions, patients have relatively high expectations of responsiveness and assurance, and it is important to note that personal safety was the most important item of the assurance dimension. Similar high expectations for the assurance dimension were measured in a study for NHS hospitals in the West Midlands region, UK. It was found that the overall highest expectation was of the assurance dimension, namely, that patients would feel secure in receiving medical care, whereas two of the lowest expectations illustrate that patients do not have a high expectation of individual attention or access to management (Youssef, Nel \& Bovaird, 1996:17).

\section{PURPOSE AND OBJECTIVES OF THE RESEARCH}

The purpose of this research is to determine service quality related to tangibility and assurance delivered in a government-controlled hospital in South Africa.

The objectives of this study are threefold, namely:

- $\quad$ To determine if equality exists between in- and out-patients in the service tangibility provided to patients in a government-controlled hospital in South Africa (perceived performance).

- To determine if equality exists between in- and out-patients in the service assurance provided to patients in a government-controlled hospital in South Africa (perceived performance).

- To determine whether the expectations of in- and out-patients regarding how hospital staff responds to their needs in terms of the tangibility and assurance variables are met (satisfaction).

In- patients refer to patients admitted in the hospital and out-patients refer to patients who receive medical consultation and/or treatment without being admitted.

The service tangibility content under investigation includes the following constructs: general condition of equipment; visual appearance of physical facilities; neat appearance of staff; convenience of parking; availability of adequate seating; quality of cafeteria services; cleanliness of ablution facilities; clear and informative signage; visibility of staff identity; cleanliness of corridors; and noise level of corridors. The service assurance content under investigation includes: treatment with dignity and respect by staff; friendliness and courtesy of staff; confidentiality of treatment; communication in a language that can be understood; communication at a level that can be understood; personal safety; safety of facilities; and safety of personal belongings.

\section{RESEARCH METHODOLOGY}

The research methodology that was followed for the investigation is consequently explained. The data analysis illustrates the levels of importance and perceived performance of two dimensions of service quality for in- and out- patients of the hospital namely, tangibility and assurance. The non-parametric test is used to determine whether significant differences exist between expectations and perceived performance for both in- and out-patients with regard to assurance and tangibility.

\section{Hypothesis}

Three primary hypotheses are tested namely:

\section{Hypothesis 1}

Ho: In- and out-patients have the same level of expectations with regards to hospital tangibility and the same level of expectations with regard to hospital assurance related variables.

$\mathrm{Ha}$ : In- and out-patients have different levels of expectations with regards to hospital tangibility and different levels of expectations with regard to hospital assurance related variables.

If the Ho hypothesis is accepted, then it can be assumed that equality exists amongst in- and outpatients and that all patients expect the same level of treatment with regards to tangibility and 
assurance. On the other hand, if the Ho hypothesis is rejected, then it is assumed that in- and outpatients inequality exists in terms of their expectations.

\section{Hypothesis 2}

Ho: There exists no significant differences between in- and out-patients with regards to the perceived performance of the hospital in terms of tangibility and no significant difference in terms of their perceived performance of service assurance related variables.

$\mathrm{Ha}$ : There exists significant differences between in- and out-patients with regards to the perceived performance of the hospital in terms of tangibility and in terms of service assurance related issues respectively.

\section{Hypotheses 3}

Ho: There exists no significant differences between in- and out patients' satisfaction levels with regards to the hospital's tangibility and assurance services respectively.

Ha: There exists significant differences between in- and out patients' satisfaction with regards to the hospital's tangibility and assurance service levels.

If the Ho hypothesis is accepted, then it implies that the expectations of patients are met, leading to a feeling of satisfaction. On the other hand, if the Ho hypothesis is rejected, then it is assumed that patients' expectations are not met which may lead to a feeling of dissatisfaction.

The null hypothesis is tested at a 0.05 significance level.

\section{Assumptions}

The researchers are of the opinion that the following assumptions can be deducted:

- If a spirit of service to the customer is installed in all employees, then: firstly, a willingness and readiness to serve customers will show in the behaviour of all employees; secondly, a prompt service will be provided to customers; and thirdly, all customers will be well-informed on all aspects that may affect their well-being.

- If a spirit of service to the customer prevails, then all customers will be treated in an equitable manner regardless gender, race or culture (De Jager \& Grundling, 2004).

\section{The Sample Framework and Data Collection}

A service satisfaction survey was conducted amongst patients treated at a provincial hospital in Gauteng, South Africa. The attitudes of the patients were tested regarding pre-identified service quality aspects related to health care. A total of 583 in- and out-patients were personally interviewed during the research. Although an attempt was made to select the patients randomly, it was not always possible due to patients that were not able and/or willing to complete the questionnaires. In such cases, substitutes were selected to overcome the problem of no-responses.

\section{The Measuring Instrument}

The measuring instrument was designed in such a manner as to enable the researchers to test the formulated hypothesis based on the two formulated assumptions. Only the tangibility and assurance categories will be reported on in this paper, namely:

- The expectations of in- and out-patients with regards to the hospital's tangibility and assurance services respectively and

- The perceptions of in- and out-patients regarding the hospital's tangibility and assurance performance. 
The two dimensions represented a mirror-image of each other. A five-point Likert type scale was used to measure the levels of perceived performance of the hospitals as well as the expectation levels of the patients. Respondents were asked to indicate their evaluation on the scales in which:

$1=$ Very important (Excellent)

$2=$ Important (Good)

$3=$ Not important nor unimportant (Neither good nor bad)

$4=$ Not important (Not good)

$5=$ Not important at all (Not good at all.)

A total of 19 items were used to measure the tangibility and assurance related variables as offered by the hospital.

An item analysis was carried out to test the validity and the reliability of the questionnaire and an overall Cronbach coefficient Alpha of 0.9369 and 0.9053 were measured for expectations and performance respectively.

\section{Data Analysis}

Data was captured by a trained assistant and analysed using the SPSS version 12 statistical package. Data was analysed after grouping the list of 53 pre-identified service related variables into five service related groupings. Only the tangibility and assurance dimensions were analysed for the purpose of this paper.

A non-parametric test, the Kruskal-Wallis test, was done to test the null -and the alternative hypothesis of the three stated hypotheses.

\section{FINDINGS}

Tables 1 and 3 illustrate the levels of importance of the tangibility and the assurance constructs in order to compare it with the perceived performance. Tables 2 and 4 illustrate the perceived performance of the two constructs that were tested. In order to ensure a logical interpretation, all the tables are divided into three sections: in-patients; out-patients; and total patients. The means are ranked in each of the sections based on the level of importance (perceived performance). Firstly, the most important (best perceived) variable as indicated by the total sample is discussed, followed by a discussion of the respective positions of the in- and out- patients with regard to the overall (total) most important variable. This is consequently done for the second, third and least important (perceived) variables.

\section{Tangibility}

It can be seen in table 1 that the patients reported fairly high expectations on the majority of the tangibility variables as opposed to the relatively low expectations reported by the study of Sohail (2003:202). This suggests that all patients demand excellent tangibility levels. The three most important variables (in terms of their expectations) for patients in general are:

- $\quad$ Cleanliness of ablution facilities (Mean: 1.66)

- General condition of equipment (Mean: 1.68)

- $\quad$ Cleanliness of the corridors (Mean: 1.71) 
Table 1: Test for differences with regards to expectations on tangibility constructs

\begin{tabular}{|c|c|c|c|c|c|c|c|c|}
\hline \multirow[b]{2}{*}{ Tangibility: } & \multirow[b]{2}{*}{ N } & \multicolumn{2}{|l|}{ In-patients } & \multicolumn{2}{|c|}{ Out-patients } & \multicolumn{2}{|c|}{ Total patients } & \multirow[b]{2}{*}{ Exp Kruska } \\
\hline & & Exp Mean & Std & Exp Mean & Std & \begin{tabular}{|l|} 
Exp \\
Mean
\end{tabular} & Std & \\
\hline General condition of equipment & 583 & $\begin{array}{l}1.89 \\
1\end{array}$ & 1.01 & $\begin{array}{l}1.44 \\
1\end{array}$ & 0.78 & $\begin{array}{l}1.68 \\
2\end{array}$ & 0.94 & $\star 0.0001$ \\
\hline $\begin{array}{l}\text { Visual appearance of Physical } \\
\text { facilities }\end{array}$ & 583 & $\begin{array}{l}2.14 \\
6\end{array}$ & 1.13 & 1.73 & 0.89 & 1.96 & 1.05 & $* 0.0001$ \\
\hline Neat appearance of staff & 583 & $\begin{array}{l}2.11 \\
5\end{array}$ & 1.13 & $\begin{array}{l}1.58 \\
4\end{array}$ & 0.81 & $\begin{array}{l}1.87 \\
5\end{array}$ & 1.03 & $\star 0.0001$ \\
\hline Convenience of parking & 583 & $\begin{array}{l}2.66 \\
11\end{array}$ & 1.38 & $\begin{array}{l}1.96 \\
10\end{array}$ & 1.27 & $\begin{array}{l}2.34 \\
11\end{array}$ & 1.37 & $\star 0.0001$ \\
\hline Availability of adequate seating & 583 & $\begin{array}{l}2.17 \\
8\end{array}$ & 1.07 & $\begin{array}{l}1.75 \\
8\end{array}$ & 1.37 & $\begin{array}{l}1.98 \\
8\end{array}$ & 1.23 & $\times 0.0001$ \\
\hline Quality of cafeteria services & 583 & $\begin{array}{l}2.35 \\
10\end{array}$ & 1.21 & $\begin{array}{l}1.84 \\
9\end{array}$ & 1.12 & 2.12 & 1.2 & $* 0.0001$ \\
\hline Cleanliness of ablution facilities & 583 & $\begin{array}{l}1.83 \\
2\end{array}$ & 1.12 & $\begin{array}{l}1.45 \\
2\end{array}$ & 0.94 & $\begin{array}{l}1.66 \\
1\end{array}$ & 1.06 & $\star 0.0001$ \\
\hline Clear and informative signage & 583 & 2.15 & 3.32 & $\begin{array}{l}1.65 \\
6\end{array}$ & 0.89 & $\begin{array}{l}1.92 \\
6\end{array}$ & 2.53 & $\star 0.0001$ \\
\hline Visibility of Staff identity & 583 & 2.07 & 1.13 & $\begin{array}{l}1.61 \\
5\end{array}$ & 0.94 & 1.86 & 1.07 & $\star 0.0001$ \\
\hline Cleanliness of corridors & 583 & $\begin{array}{l}1.85 \\
3\end{array}$ & 0.98 & $\begin{array}{l}1.56 \\
3\end{array}$ & 0.85 & 1.71 & 0.94 & 0.26 \\
\hline Noise level of corridors & 583 & $\begin{array}{l}2.27 \\
9\end{array}$ & 3.06 & $\begin{array}{l}1.98 \\
11 \\
\end{array}$ & 1.08 & $\begin{array}{l}2.14 \\
10 \\
\end{array}$ & 2.37 & $\times 0.0001$ \\
\hline Total Tangibility: & 583 & 2.14 & 1.72 & 1.69 & 1.03 & 1.93 & 1.46 & \\
\hline
\end{tabular}

Table 2 indicates that the variable that is overall perceived best in the tangibility category is the neat appearance of the staff and is perceived significantly better by out-patients rating it first, while it is rated in fourth position by in-patients. This variable is overall rated as the fifth most important variable in this category. Clear and informative signage is overall rated second in terms of perceived performance. No significant differences between in- and out-patients are measured and the rating is similar, second and third respectively. The overall third best perceived variable in this category is the general condition of the hospital's equipment with out-patients perceiving it better, although no significant differences are measured between the means. However, there are significant differences between the ratings of the respective groups, with in-patients rating it significantly better (in first place) compared to a fifth place by out-patients. This implies that, although the means are very similar, the out-patients regarded other variables as more important than the general condition of the hospital's equipment. The variable that is overall perceived in the last position is the convenience of parking facilities with in-patients that have a more negative perception. However, no significant differences are measured between the two groups and the ratings are the same in eleventh position. Interesting to note is that this variable is rated least important (table 1) by the patients in general. However, in this case, significant differences between the two patient groups with regards to this finding exist. Overall, it seems as if, in most instances, no significant differences exist between the in- and out-patients with regards to the perceived tangibility construct. The null hypothesis is therefore accepted.

\section{Assurance}

In table 3 , it can be seen that the patients reported fairly high expectations regarding the majority of the assurance variables. The findings are consistent with those of Youssef, Nel and Bovaird (1996), while Sohail (2003:202) reported generally low expectations for the assurance dimensions for private hospital patients in Malaysia. This suggests that all patients demand excellent assurance related service levels. The three most important issues (in terms of their expectations) for patients in general are:

- $\quad$ Personal safety (Mean: 1.59)

- $\quad$ Friendliness and courtesy of staff (Mean: 1.64)

- $\quad$ Communication at an understandable level (Mean: 1.65) 
Table 2: Test for significant differences with regards to perceived performance on tangibility constructs

\begin{tabular}{|c|c|c|c|c|c|c|c|c|}
\hline \multirow[b]{2}{*}{ Tangibility: } & \multirow[b]{2}{*}{$\mathbf{N}$} & \multicolumn{2}{|c|}{ In-patients } & \multicolumn{2}{|c|}{ Out-patients } & \multicolumn{2}{|c|}{ Total patients } & \multirow[b]{2}{*}{ Prf Kruska } \\
\hline & & Prf Mean & Std & Prf Mean & Std & Prf Mean & Std & \\
\hline General condition of equipment & 583 & $\begin{array}{l}2.22 \\
1\end{array}$ & 1.08 & $\begin{array}{l}2.21 \\
5\end{array}$ & 1.16 & $\begin{array}{l}2.21 \\
3\end{array}$ & 1.11 & 0.48 \\
\hline $\begin{array}{l}\text { Visual appearance of Physical } \\
\text { facilities }\end{array}$ & 583 & $\begin{array}{l}2.79 \\
10\end{array}$ & 1.14 & $\begin{array}{l}2.68 \\
10\end{array}$ & 1.28 & $\begin{array}{l}2.74 \\
10\end{array}$ & 1.20 & 0.14 \\
\hline Neat appearance of staff & 583 & $\begin{array}{l}2.36 \\
4\end{array}$ & 1.21 & $\begin{array}{l}1.95 \\
1\end{array}$ & 1.02 & $\begin{array}{l}2.17 \\
1\end{array}$ & 1.15 & $\star 0.0001$ \\
\hline Convenience of parking & 583 & $\begin{array}{l}2.87 \\
11\end{array}$ & 1.25 & $\begin{array}{l}2.69 \\
11\end{array}$ & 1.39 & $\begin{array}{l}2.78 \\
11\end{array}$ & 1.32 & 0.06 \\
\hline Availability of adequate seating & 583 & $\begin{array}{l}2.57 \\
6\end{array}$ & 1.2 & $\begin{array}{l}2.59 \\
8\end{array}$ & 1.32 & $\begin{array}{l}2.58 \\
7\end{array}$ & 1.25 & 0.73 \\
\hline Quality of cafeteria services & 583 & $\begin{array}{l}2.74 \\
9\end{array}$ & 1.18 & $\begin{array}{l}2.50 \\
7\end{array}$ & 1.2 & $\begin{array}{l}2.63 \\
8\end{array}$ & 1.20 & $\star 0.009$ \\
\hline Cleanliness of ablution facilities & 583 & 2.69 & 1.3 & $\begin{array}{l}2.36 \\
6\end{array}$ & 1.29 & $\begin{array}{l}2.54 \\
6\end{array}$ & 1.31 & $\star 0.001$ \\
\hline Clear and informative signage & 583 & $\begin{array}{l}2.23 \\
2\end{array}$ & 0.96 & $\begin{array}{l}2.20 \\
3 \\
\end{array}$ & 1.18 & $\begin{array}{l}2.21 \\
2\end{array}$ & 1.06 & 0.17 \\
\hline Visibility of Staff identity & 583 & $\begin{array}{l}2.24 \\
3\end{array}$ & 1.16 & $\begin{array}{l}2.20 \\
3\end{array}$ & 1.16 & 2.22 & 1.16 & 0.64 \\
\hline Cleanliness of corridors & 583 & $\begin{array}{l}2.38 \\
5\end{array}$ & 0.99 & $\begin{array}{l}2.17 \\
2\end{array}$ & 0.97 & $\begin{array}{l}2.28 \\
5\end{array}$ & 0.99 & $\star 0.005$ \\
\hline Noise level of corridors & 583 & $\begin{array}{l}2.70 \\
8\end{array}$ & 1.23 & $\begin{array}{l}2.65 \\
9\end{array}$ & 1.22 & $\begin{array}{l}2.68 \\
9\end{array}$ & 1.23 & 0.65 \\
\hline Total Tangibility: & 583 & 2.53 & 1.18 & 2.4 & 1.22 & 2.46 & 1.20 & \\
\hline
\end{tabular}

*Significant on 0.95 level Std= Standard deviation

Table 3: Test for differences with regards to expectations on assurance constructs

\begin{tabular}{|c|c|c|c|c|c|c|c|c|}
\hline \multirow[b]{2}{*}{ Assurance: } & \multirow[b]{2}{*}{$\mathbf{N}$} & \multicolumn{2}{|c|}{ In-patients } & \multicolumn{2}{|c|}{ Out-patients } & \multicolumn{2}{|c|}{ Total patients } & \multirow[b]{2}{*}{ Exp Kruska } \\
\hline & & Mean & Std & Mean & Std & Mean & Std & \\
\hline $\begin{array}{l}\text { Treatment with dignity and respect } \\
\text { by staff }\end{array}$ & 583 & $\begin{array}{l}1.74 \\
4\end{array}$ & 0.92 & $\begin{array}{l}1.15 \\
6\end{array}$ & 0.87 & $\begin{array}{l}1.66 \\
4\end{array}$ & 0.9 & $\star 0.007$ \\
\hline Friendliness and courtesy of staff & 583 & $\begin{array}{l}1.67 \\
1\end{array}$ & 0.75 & $\begin{array}{l}1.16 \\
7\end{array}$ & 0.88 & $\begin{array}{l}1.64 \\
2\end{array}$ & 0.81 & $\star 0.016$ \\
\hline Confidentially of treatment & 583 & $\begin{array}{l}1.90 \\
8\end{array}$ & 1.01 & 1.11 & 0.74 & $\begin{array}{l}1.69 \\
5\end{array}$ & 0.92 & $\star 0.0001$ \\
\hline $\begin{array}{l}\text { Communication in a language that } \mathrm{I} \\
\text { can understand }\end{array}$ & 583 & $\begin{array}{l}1.83 \\
7\end{array}$ & 1.03 & $\begin{array}{l}1.14 \\
5\end{array}$ & 0.89 & $\begin{array}{l}1.66 \\
4\end{array}$ & 0.99 & $\star 0.0001$ \\
\hline $\begin{array}{l}\text { Communication at a level that I can } \\
\text { understand }\end{array}$ & 583 & $\begin{array}{l}1.78 \\
5\end{array}$ & 0.98 & $\begin{array}{l}1.11 \\
1\end{array}$ & 0.79 & $\begin{array}{l}1.65 \\
3\end{array}$ & 0.91 & $\star 0.0001$ \\
\hline Personal safety & 583 & $\begin{array}{l}1.70 \\
2\end{array}$ & 0.85 & $\begin{array}{l}1.12 \\
3\end{array}$ & 0.75 & $\begin{array}{l}1.59 \\
1\end{array}$ & 0.81 & $\star 0.0001$ \\
\hline Safety of facilities & 583 & 1.80 & 0.92 & 1.13 & 0.76 & $\begin{array}{l}1.66 \\
4\end{array}$ & 0.87 & $\star 0.0001$ \\
\hline Safety of personal belongings & 583 & $\begin{array}{l}1.72 \\
3\end{array}$ & 0.93 & $\begin{array}{l}1.17 \\
8\end{array}$ & 0.92 & $\begin{array}{l}4.65 \\
3\end{array}$ & 0.93 & $\star 0.008$ \\
\hline Total Assurance: & 583 & 1.77 & 0.93 & 1.13 & 0.83 & 1.65 & 0.89 & \\
\hline
\end{tabular}

*Significant on 0.95 level

Std $=$ Standard deviation

In table 4, it can be seen that the variable that is overall perceived best in the assurance category is communication at an understandable level and is perceived better by out-patients. No significant differences between in- and out patients' perceptions are measured and similar ratings are given (first and second position respectively). This variable is overall rated as the third most important variable in this category.

Communication in an understandable language is overall rated second in terms of perceived performance. Significant differences between in- and out-patients are measured with out-patients perceiving it significantly better compared to in-patients. However, it is rated similar (first and second position). The third best perceived variable is the personal safety of patients. While no significant 
differences are measured between the two groups, the rating is also similar, in third and fourth position. This variable is overall rated the most important variable in the assurance category. The variable that is overall perceived in last position is the safety issues of the facilities with in-patients that have a significantly more negative perception. Interesting to note is that this variable is regarded as the fourth most important issue by the patients in general. In conclusion: significant differences are measured in terms of all the variables in the assurance construct. Thus, the null hypotheses are rejected.

Table 4: Test for significant differences with regards to perceived performance on assurance constructs

\begin{tabular}{|c|c|c|c|c|c|c|c|c|}
\hline \multirow[b]{2}{*}{ Assurance: } & \multirow[b]{2}{*}{$\mathbf{N}$} & \multicolumn{2}{|l|}{ In-patients } & \multicolumn{2}{|c|}{ Out-patients } & \multicolumn{2}{|c|}{ Total patients } & \multirow[b]{2}{*}{ Prf Kruska } \\
\hline & & Prf Mean & Std & Prf Mean & Std & Prf Mean & Std & \\
\hline $\begin{array}{l}\text { Treatment with dignity and } \\
\text { respect by staff }\end{array}$ & 583 & 2.42 & 1.62 & $\begin{array}{l}2.03 \\
3 \\
\end{array}$ & 1.07 & $\begin{array}{l}2.24 \\
6 \\
\end{array}$ & 2.24 & $\star 0.0009$ \\
\hline Friendliness and courtesy of staff & f 583 & $\begin{array}{l}2.28 \\
5\end{array}$ & 1.1 & 2.11 & 1.1 & $\begin{array}{l}2.2 \\
5\end{array}$ & 2.20 & ${ }^{*} 0.03$ \\
\hline Confidentially of treatment & 583 & $\begin{array}{l}2.11 \\
4\end{array}$ & 0.98 & $\begin{array}{l}2.08 \\
5\end{array}$ & 2.77 & $\begin{array}{l}2.09 \\
4\end{array}$ & 2.09 & $\times 0.0008$ \\
\hline $\begin{array}{l}\text { Communication in a language } \\
\text { that I can understand }\end{array}$ & 583 & $\begin{array}{l}2.00 \\
2\end{array}$ & 1.09 & $\begin{array}{l}1.86 \\
1\end{array}$ & 1.18 & $\begin{array}{l}1.94 \\
2\end{array}$ & 1.94 & $\times 0.03$ \\
\hline $\begin{array}{l}\text { Communication at a level that I } \\
\text { can understand }\end{array}$ & 583 & $\begin{array}{l}1.94 \\
1\end{array}$ & 0.99 & $\begin{array}{l}1.88 \\
2\end{array}$ & 0.9 & $\begin{array}{l}1.91 \\
1\end{array}$ & 1.91 & 0.74 \\
\hline Personal safety & 583 & $\begin{array}{l}2.07 \\
3\end{array}$ & 1.03 & $\begin{array}{l}2.06 \\
4\end{array}$ & 1.17 & $\begin{array}{l}2.06 \\
3\end{array}$ & 2.06 & 0.32 \\
\hline Safety of facilities & 583 & $\begin{array}{l}2.46 \\
8\end{array}$ & 1.2 & $\begin{array}{l}2.08 \\
5\end{array}$ & 1.04 & $\begin{array}{l}2.29 \\
8\end{array}$ & 2.29 & $* 0.0001$ \\
\hline Safety of personal belongings & 583 & $\begin{array}{l}2.32 \\
6 \\
\end{array}$ & 1.48 & $\begin{array}{l}2.22 \\
8\end{array}$ & 1.27 & $\begin{array}{l}2.27 \\
7\end{array}$ & 2.27 & 0.88 \\
\hline Total Assurance: & 583 & 2.2 & 1.22 & 2.04 & 1.37 & 2.13 & 1.32 & \\
\hline
\end{tabular}

Significant on 0.95 level Std= Standard deviation

\section{Satisfaction}

A non-parametric test procedure is used to compare the patient's expectations with regard to the tangibility variables with their perceived performance of the hospital (this was also done for the assurance related variables). The test computes the differences between the mean values of two variables for each case and tests whether the average differs significantly from 0 . This test could be used as the observations for each variable pair was made under the same conditions. The aim was to determine whether performance on both tangibility and assurance matches the expectations of patients or not.

Table 5 indicates that significant differences exist between expectations and perceived performance for both in- and out-patients on all tangibility variables. This is an indication that patient's expectations have not been met. The overall smallest deviation between expectations and perceived performance is measured in terms of clear and informative signage where out-patients are significantly less satisfied with the particular service. This variable is however overall rated sixth in terms of importance. The second smallest deviation between expectations and perceived performance is measured in terms of neat appearance of the staff with in-patients expressing a more positive perception. However, overall this variable is indicated as of moderate importance.

The biggest overall deviation between expectations and perceived performance is measured in terms of the cleanliness of the ablution facilities. This variable is rated the most important variable in the tangibility category.

Table 6 indicates that significant differences between expectations and perceived performance exist for both in- and out-patients on all assurance variables. This is an indication that expectations have not been met in terms of any of the variables. The overall smallest deviation between expectations and perceived performance is measured in terms of communication at a level that can be understood. 
The second smallest deviation is communication in a language that can be understood regarding explanation of hospital procedure. Both these variables are rated fairly high in terms of importance.

Table 5: Test for significant differences between expectations and perceived performance of tangibility

\begin{tabular}{|c|c|c|c|c|c|c|c|c|c|c|c|}
\hline \multirow[b]{2}{*}{ Tangibility: } & \multicolumn{4}{|c|}{ In-patients } & \multicolumn{4}{|c|}{ Out-patients } & \multicolumn{3}{|c|}{ Total patients } \\
\hline & $\begin{array}{l}\text { Exp } \\
\text { Mean }\end{array}$ & $\begin{array}{l}\text { Prf } \\
\text { Mean } \\
\end{array}$ & Gap & \begin{tabular}{|l|} 
Kruska \\
Gap
\end{tabular} & $\begin{array}{l}\text { Exp } \\
\text { Mean }\end{array}$ & \begin{tabular}{|l} 
Prf \\
Mean \\
\end{tabular} & Gap & $\begin{array}{l}\text { Kruska } \\
\text { Gap }\end{array}$ & $\begin{array}{l}\text { Exp } \\
\text { Mean }\end{array}$ & \begin{tabular}{|l|} 
Prf \\
Mean
\end{tabular} & Gap \\
\hline $\begin{array}{l}\text { General condition of } \\
\text { equipment }\end{array}$ & 1.89 & 2.22 & $\begin{array}{l}-0.33 \\
5\end{array}$ & $\star 0.0001$ & 1.44 & 2.20 & $\begin{array}{l}-0.76 \\
8\end{array}$ & $\star 0.0001$ & 1.68 & 2.21 & $\begin{array}{l}-0.52 \\
6\end{array}$ \\
\hline $\begin{array}{l}\text { Visual appearance of } \\
\text { Physical }\end{array}$ & 2.14 & 2.79 & $\begin{array}{l}-0.65 \\
10\end{array}$ & $\star 0.0001$ & 1.73 & 2.68 & $\begin{array}{l}-0.95 \\
11 \\
\end{array}$ & $\star 0.0001$ & 1.96 & 2.74 & $\begin{array}{l}-0.78 \\
10\end{array}$ \\
\hline Neat appearance of staff & 2.11 & 2.36 & $\begin{array}{l}-0.24 \\
4\end{array}$ & $\star 0.01$ & 1.58 & 1.95 & $\begin{array}{l}-0.37 \\
1\end{array}$ & $\star 0.0001$ & 1.87 & 2.17 & $\begin{array}{l}-0.30 \\
2\end{array}$ \\
\hline Convenience of parking & 2.66 & 2.87 & $\begin{array}{l}-0.21 \\
3 \\
\end{array}$ & ${ }^{*} 0.01$ & 1.96 & 2.69 & $\begin{array}{l}-0.73 \\
7\end{array}$ & $\star 0.0001$ & 2.34 & 2.78 & $\begin{array}{l}-0.44 \\
4\end{array}$ \\
\hline $\begin{array}{l}\text { Availability of adequate } \\
\text { seating }\end{array}$ & 2.17 & 2.57 & -0.4 & $\star 0.0001$ & 1.75 & 2.59 & $\begin{array}{l}-0.84 \\
9\end{array}$ & $\star 0.0001$ & 1.98 & 2.58 & $\begin{array}{l}-0.60 \\
9\end{array}$ \\
\hline Quality of cafeteria services & 2.35 & 2.74 & $\begin{array}{l}-0.39 \\
6\end{array}$ & $\star 0.0001$ & 1.84 & 2.5 & $\begin{array}{l}-0.66 \\
5\end{array}$ & $\star 0.0001$ & 2.12 & 2.63 & $\begin{array}{l}-0.51 \\
5\end{array}$ \\
\hline $\begin{array}{l}\text { Cleanliness of ablution } \\
\text { facilities }\end{array}$ & 1.83 & 2.69 & $\begin{array}{l}-0.86 \\
11 \\
\end{array}$ & $\star 0.0001$ & 1.45 & 2.36 & $\begin{array}{l}-0.91 \\
10 \\
\end{array}$ & $\star 0.0001$ & 1.66 & 2.54 & $\begin{array}{l}-0.88 \\
11 \\
\end{array}$ \\
\hline Clear and informative signage & 2.15 & 2.23 & $\begin{array}{l}-0.08 \\
1\end{array}$ & ${ }^{*} 0.0001$ & 1.65 & 2.20 & $\begin{array}{l}-0.55 \\
2 \\
\end{array}$ & $\star 0.0001$ & 1.92 & 2.21 & $\begin{array}{l}-0.29 \\
1\end{array}$ \\
\hline Visibility of Staff identity & 2.07 & 2.24 & $\begin{array}{l}-0.18 \\
2\end{array}$ & ${ }^{*} 0.045$ & 1.61 & 2.20 & $\begin{array}{l}-0.59 \\
3\end{array}$ & $* 0.0001$ & 1.86 & 2.22 & $\begin{array}{l}-0.36 \\
3\end{array}$ \\
\hline Cleanliness of corridors & 1.85 & 2.38 & $\begin{array}{l}-0.53 \\
9\end{array}$ & $\star 0.0001$ & 1.56 & 2.17 & $\begin{array}{l}-0.61 \\
4\end{array}$ & $\star 0.0001$ & 1.71 & 2.28 & $\begin{array}{l}-0.57 \\
8\end{array}$ \\
\hline Noise level of corridors & 2.27 & 2.7 & $\begin{array}{l}-0.43 \\
8\end{array}$ & ${ }^{*} 0.0001$ & 1.98 & 2.65 & $\begin{array}{l}-0.67 \\
6\end{array}$ & $\star 0.0001$ & 2.14 & 2.68 & $\begin{array}{l}-0.54 \\
7\end{array}$ \\
\hline Total Tangibility: & 2.14 & 2.53 & -0.39 & & 1.69 & 2.38 & -0.69 & & 1.93 & 2.46 & -0.51 \\
\hline
\end{tabular}

*Significant on 0.95 level

Table 6: Test for significant differences between expectations and perceived performance of assurance

\begin{tabular}{|c|c|c|c|c|c|c|c|c|c|c|c|}
\hline \multirow[b]{2}{*}{ Assurance : } & \multicolumn{4}{|c|}{ In-patients } & \multicolumn{4}{|c|}{ Out-patients } & \multicolumn{3}{|c|}{ Total patients } \\
\hline & $\begin{array}{l}\text { Exp } \\
\text { Mean }\end{array}$ & \begin{tabular}{|l} 
Prf \\
Mean
\end{tabular} & Gap & $\begin{array}{l}\text { Kruska } \\
\text { Gap }\end{array}$ & \begin{tabular}{|l} 
Exp \\
Mean
\end{tabular} & \begin{tabular}{|l} 
Prf \\
Mean
\end{tabular} & Gap & $\begin{array}{l}\text { Kruska } \\
\text { Gap }\end{array}$ & $\begin{array}{l}\text { Exp } \\
\text { Mean }\end{array}$ & \begin{tabular}{|l} 
Prf \\
Mean
\end{tabular} & Gap \\
\hline $\begin{array}{l}\text { Treatment with dignity and } \\
\text { respect by staff }\end{array}$ & 1.74 & 2.42 & -0.68 & $\star 0.0001$ & 1.57 & 2.03 & -0.45 & $\star 0.0001$ & 1.66 & 2.24 & -0.58 \\
\hline $\begin{array}{l}\text { Friendliness and courtesy of } \\
\text { staff }\end{array}$ & 1.67 & 2.28 & -0.61 & $\times 0.0001$ & 1.59 & 2.11 & -0.51 & ${ }^{*} 0.0001$ & 1.64 & 2.2 & -0.56 \\
\hline Confidentially of treatment & 1.9 & 2.11 & -0.21 & $\times 0.0017$ & 1.45 & 2.08 & -0.62 & $\star 0.0001$ & 1.69 & 2.09 & -0.40 \\
\hline $\begin{array}{l}\text { Communication in a language } \\
\text { that I can understand }\end{array}$ & 1.83 & 2.00 & -0.17 & $\star 0.03$ & 1.46 & 1.86 & -0.41 & $\star 0.0001$ & 1.66 & 1.94 & -0.28 \\
\hline $\begin{array}{l}\text { Communication at a level that } \\
\text { I can understand }\end{array}$ & 1.78 & 1.94 & -0.16 & ${ }^{*} 0.02$ & 1.5 & 1.88 & -0.38 & $\star 0.0001$ & 1.65 & 1.91 & -0.26 \\
\hline Personal safety & 1.7 & 2.07 & -0.37 & $\star 0.0001$ & 1.45 & 2.06 & -0.61 & $\star 0.0001$ & 1.59 & 2.06 & -0.48 \\
\hline Safety of facilities & 1.8 & 2.46 & -0.66 & $\star 0.0001$ & 1.5 & 2.08 & -0.59 & $\star 0.0001$ & 1.66 & 2.29 & -0.63 \\
\hline Safety of personal belongings & 1.72 & 2.32 & -0.6 & $\times 0.0001$ & 1.57 & 2.22 & -0.65 & $\star 0.0001$ & 1.65 & 2.27 & -0.62 \\
\hline Total Assurance: & 1.77 & 2.2 & -0.43 & & 1.51 & 2.04 & -0.53 & & 1.65 & 2.13 & -0.48 \\
\hline
\end{tabular}

*Significant on 0.95 level

Finally, a regression analysis was performed to determine which tangible and assurance variables contribute significantly to the overall satisfaction with the hospital. The results indicated that the following variables contribute significantly to the overall satisfaction of the hospital. 
- Neat appearance of the staff

- Treatment with dignity and respect

- Communication at a level that can be understood

- Communication in a language that can be understood

\section{MANAGEMENT IMPLICATIONS}

The results of the investigation hold important implications for future planning and development in the South African health care industry and more specifically, public hospitals. Service managers should take note of the most important service quality issues identified in this investigation. In this regard, the cleanliness of facilities and the general condition of equipment were regarded as the most important tangibility variables. Personal safety and friendliness and courtesy of staff have been identified as the most important assurance variables. Consequently, it is important to communicate these findings to the respective individuals or groups that take responsibility for satisfying customer needs, in particular public hospitals.

These findings should contribute towards a constructive paradigm shift and an improved perception of service delivery, especially, but not necessarily limited to the public health sector. Based on the findings of this study, the two most significant strategies that can be recommended in the public health sector should consist of investment in, firstly, an analysis of patients' perceptions of the performance of a hospital on an ongoing and formalised basis and secondly, of proper staff and management training sessions. Moreover, the prominence of the variables related to assurance in the findings suggests that these aspects of service delivery should be addressed accordingly. Particularly, with regards to specific outcomes, service managers should be aware of the poor performance in the tangibility dimension, such as visual appearance of physical facilities and noise levels in corridors and, correspondingly, the poor performance in the assurance dimension such as the safety of facilities and personal belongings.

The literature consulted in this study also provides relevant recommendations that may augment or compliment the resultant strategies derived from the findings of the empirical study. Notably, the most pertinent literature (Lee, Lee \& Yoo, 2000:230) suggests that efforts should be directed towards satisfaction outcomes. This implies that, instead of concentrating on performance outcomes, attention should be directed towards maintaining satisfaction in areas where high levels of satisfaction are observed. The application thereof can be advantageous in refining the strategies recommended in this study, where significantly high levels of satisfaction were measured in terms of clear and informative signage in the tangibility dimension and communication at a level that could be understood by the patient in the assurance dimension.

\section{CONCLUSION}

The study established that the perceived performance of the hospital with regards to the two constructs under investigation are not meeting or exceeding the expectations of the patients. Consequently, when applying the gap model, patients experience a sense of dissatisfaction with regards to the services rendered. It also appeared that, where patients' expectations were almost met, they were regarded as having a relatively insignificant influence on the overall expectations, because they appear to be applicable to relatively unimportant issues. The findings clearly established that a climate of dissatisfaction exists with regards to unmet expectations and that the main concerns relate to hygiene, state of the art equipment, safety and caring.

Furthermore, the influence of external conditions, with particular reference to insufficient, ineffective government funding and the ongoing socio-political transformational challenges in public health service delivery, should be considered as a fundamental constraint. However, the counterbalance thereto should include a pro-active approach to service delivery by public health service management. This can be initiated at public hospital level through the implementation of the strategies recommended in the study, most importantly continuous assessment and training. In addition, public healthcare service delivery would benefit from health care managers and policy makers engaging in high level negotiations in order to find and allocate additional resources. Their joint motivation for increased government funding combined with improved service delivery policies would ultimately result in improved service quality in the public health care system. 
It can also be concluded that service quality in public health care service delivery can be improved by a structured and continuous process of investigating and addressing patients' perceptions of service delivery. Management should put measures in place to address the most important issues that are not satisfied. In the tangibility category, the cleanliness of the ablution facilities should be addressed as this issue is often pointed out as the main reason for dissatisfaction in the health care industry. This may be as the result of people being more hygiene conscious when undergoing medical treatment. Secondly, the general condition of the equipment should be addressed, as this is the second most important variable in the tangibility category whereas, in the assurance category, personal safety and friendliness of the staff should be addressed as a matter of urgency. The common denominator in both instances is the people tasked to render the respective services and therefore the perceived performance of a hospital can be improved through the implementation of training programmes with the objective of addressing these important issues.

The findings of this study clearly identify important positive and negative perceptions regarding the health care services provided by the hospital under examination and substantiate the conclusion that it is imperative that the hospital management take the necessary measures to improve the perceived performance of the hospital.

\section{REFERENCES}

Babakus E \& Boller GW. 1992. An empirical assessment of the SERVQUAL scale. Journal of Business Research, 24:253-68.

Baltussen R, Haddad S \& Sauerborn R. 2002. Perceived quality of care of primary health care services in Burkina Faso. Health Policy and Planning, 17(2):42-8.

Bansal MK. 2004. Optimising value and quality in general practice within the primary health care sector through relationship marketing: a conceptual framework. International Journal of Health Care Quality Assurance, 17(4):180-188.

Berry LL \& Parasuraman A. 1991. Marketing services. Competing through quality. New York: The free press.

Berry LL, ZeithamI V \& Parasuraman A. 1988. The service-quality puzzle. Business Horizons, SeptOct: 35-43.

Boshoff C \& Gray B. 2004. The relationship between service quality, customer satisfaction and buying intentions in the private hospital industry. South African Journal of Business Management, 35(4):27-37.

Butler D, Oswald SL \& Turner DE. 1996. The effects of demographics on determinants of perceived health-care service quality: The case of users and observers. Journal of Management in Medicine, 10(5):8-20

Branssington F \& Pettit S. 2000. Principles of Marketing. London: Pitman Publishing.

Brown SW \& Swartz TA. 1989. A gap analysis of professional service quality, Journal of Marketing, 53:92-8.

Butler D, Oswald SL \& Turner DE. 1996. The effects of demographics on determinants of perceived health-care service quality: The case of users and observers. Journal of Management in Medicine, 10(2):8-20.

Buttle F. 1996. SERVQUAL: Review, critique, research agenda. European Journal of Marketing, 30(1):8-32.

Cadotte ER, Woodruff RB \& Jenkins RL. 1987. Expectations and Norms of Customer Satisfaction. Journal of Marketing Research, 24:305-314. 
Cronin JJ \& Taylor S. 1992. Measuring Service Quality: A re-examination and extension. Journal of Marketing, 56(3):55-62.

De Jager JW \& Grundling J. 2004. Patient inequality: Hospital responsiveness favours women. International Academy of African Business Development Conference. Atlanta. April.

Eiriz V \& Figueiredo AF. 2005. Quality evaluation in health care services based on customerprovider relationships. International Journal of Health Care Quality Assurance, 18(6):404-12.

Grönroos C. 1990. Service Management and Marketing. Massachusetts: Lexington Books.

Jabnoun N \& Chaker M. 2003. Comparing the quality of private and public hospitals. Managing Service Quality, 3(4):290-99.

Johnson R. 1995. The determinants of service quality: satisfiers and dissatisfies. International Journal of Service Industry Management, 6(5): 53-71.

Kilbourne WE, Duffy J, Duffy M \& Giarchi G. 2004. The applicability of SERVQUAL in crossnational Measurements of health-care quality. Journal of Services Marketing, 18(7):524-533.

Lam SSK \& Woo KS. 1997. Measuring service quality: A test-retest reliability investigation of SERVQUAL. Journal of the Market Research Society, 39(2):381-396.

Mahomed H \& Bachmann MO. 1998. Block appointments in an overloaded South African health centre: quantitative and qualitative evaluation. International Journal of Health Care Quality Assurance, 11(4):123-126.

Manaf NHA. 2005. Quality management in Malaysian public health care. International Journal of Health Care Quality Assurance, 18(3):204-216.

Mitchell T. 2000. Patient Satisfaction survey. Pretoria Academic Hospital. Unpublished report.

Mostafa MM. 2005. An empirical study of patients' expectations and satisfactions in Egyptian hospitals. International Journal of Health Care Quality Assurance, 18(7):516-532.

O'Connor SJ, Trinh HO \& Shewchuk RM. 2000. Perceptual gaps in understanding patient's expectations for Health Care Service Quality. Health care management Review, 25(2):7-23.

Oliver R. 1980. A Cognitive Model of antecedents and consequences of satisfaction. Journal of Marketing Research, 17(4):460-469

Orava M \& Tuominen P. 2002. Curing and caring in surgical services: a relationship approach. Journal of Service Marketing, 16(7):677-91.

Ovretveit J. 2004. Formulating a health quality improvement strategy. International Journal of Health Care Quality Assurance, 17(3):368-76.

Parasuraman A, ZeithamI V \& Berry LL. 1985. A conceptual model of service quality and its implications for further research. Journal of Marketing, 49(4):41-50.

Parasuraman A, Zeithaml V \& Berry LL. 1988. SERVQUAL: a multiple item scale for measuring customer perceptions of service quality. Journal of Retailing, 64(1):12-37.

Parasuraman A, Zeithaml V \& Berry LL. 1994. A reassessment of expectation as a comparative standard in measuring service quality: implications for future research. Journal of Marketing, 58(1):111-24.

Ramani KV. 2004. Practical Applications: a management information system to plan and monitor the delivery of health-care services in government hospitals in India. Journal of Health Organization and Management, 18(3):207-220. 
Ramsaran-Fowdar RR. 2005. Identifying Health Care Quality Attributes. Journal of health and Human Services Administration, Spring:428-443.

Sage GC. 1991. Customers and the NHS. International Journal of Health Quality Assurance, 4(3):2334.

Salomon L, Gasquet I, Mounir M \& Ravaud P. 1999. Construction of a scale measuring inpatient's opinion on quality of care. International Journal for Quality in Health Care, 11(6):507-16.

Santos J. 2002. From intangibility to tangibility on service quality perceptions: a comparative study between consumers and service providers in four service industries. Managing Service Quality, 12(5):292-302.

Sewel N. 1997. Continues quality improvement in acute health care: creating a holistic and integrated approach. International Journal for Health Care Quality Assurance, 10(1):20-26.

Singh J. 1990. A multifaceted typology of patient satisfaction with a hospital. Journal of Health Care Marketing, 10(4):8-21.

Sohail M. 2003. Service quality in hospitals: more favourable than you might think. Managing Service Quality, 13(2):197-206.

Vandamme R \& Leunis J. 1993. The development of multiple-item scale for measuring hospital service quality. International Journal of Service Industry management. 4(3):30-49.

Whittaker S, Green-Thomson RW, Mccusker I \& Nyembezi B. 2000. Status of a health care review programme in South Africa. International Journal of for Health Care, 12(3):247-250.

Wong J. 2002, Service quality measurement in a medical imaging department. International Journal of Health Care Quality Assurance, 15(2):206-12.

www.southafrica.info

Youssef FN, Nel D \& Bovaird T. 1996. A Health care quality in NHS hospitals. International Journal of Health Care Quality Assurance, 9(1):15-28.

ZeithamI VA \& Bitner MJ. 1996, Services Marketing. New York:The McGraw-Hill Companies, Inc.

ZeithamI VA, Parasuraman A \& Berry LL. 1990. Delivering quality service. New York: The free press.

Zineldin M. 2006. The quality of health care and patient satisfaction: An exploratory investigation of the 5Qs model at some Egyptian and Jordanian medical clinics. International Journal of Health Care Quality Assurance, 19(1):60-92.

Van der Schee E, Groenewegen PP \& Friele RD. 2006. Public trust in health care: a performance indicator? Journal of Health Organisation and Management, 20(5):349-358. 